\title{
First capture of Micronycteris homezi Pirlot (Chiroptera, Phyllostomidae) in Brazil
}

\section{Enrico Bernard ${ }^{1}$}

\begin{abstract}
The first capture of the phyllostomid bat Micronycteris homezi Pirlot, 1867 in Brazil is reported. An adult male was captured in a forest fragment in Alter do Chão, Santarám, Pará State, in May $7^{\text {th }}$, 1998. A description of the species, previously reported only in Venezuela and French Guiana, is given, as well as the measures of the captured specimen. After this report, the bat fauna of Brazil is composed by 139 species.

KEY WORDS. Chiroptera, Phyllostomidae, Micronycteris homezi, Amazon forest, bats, biodiversity, Brazil
\end{abstract}

Recent revisions indicate that the genus Micronycteris Gray, 1866 is not monophyletic (see SIMMONS \& Voss 1998), and as consequence, four genera should be recognized in adition to Micronycteris sensu stricto: Glyphonycteris Thomas, 1896 (including G. behnii (Peters, 1865), G. daviesi (Hill, 1964), and G. sylvestris Thomas, 1896), Lampronycteris Sanborn, 1949 (for L. brachyotis (Dobson, 1879)), Neonycteris Sanborn, 1949 (for N. pusilla (Sanborn, 1949)), and Trinycteris Sanborn, 1949 (for T. nicefori (Sanborn, 1949)). Therefore, the genus Micronycteris include $M$. hirsuta (Peters, 1869), M. megalotis (Gray, 1842), M. microtis Miller, 1898, M. minuta (Gervais, 1856), M. sanborni Simmons, 1996, M. schmidtorum Sanborn, 1935, M. brosseti Simmons \& Voss, 1998, and M. homezi Pirlot, 1967 (SimMONS \& Voss 1998). The later species was originally described by PIRLOT (1967) as a subespecies of $M$. megalotis, based on three specimens collected in the western Venezuelan state of Zulia. The fact that the three specimen (including the holotype) were destroyed during the 1970 's, associated with an incomplete description of the species, and several features not related to M. megalotis, were used to consider M. homezi as nomen dubium until recently (SIMMONS 1996). However, in 1994, during a species survey in lowland forests of Paracou, French Guiana, an exemplar of Micronycteris, with several characters close related to the PIRLOT's (1967) original discription, was collected and positively identified as M. homezi (SIMMONS \& Voss 1998). Then, the authors provided the following emended diagnosis of $M$. homezi:

Micronycteris homezi: a small species of Micronycteris with dark brown dorsal fur and pale (gray or buff) ventral fur; dorsal hairs bicolored, 7-8 $\mathrm{mm}$ long in shoulder region, with white bases comprising 1/4-1/2 of each hair; fur on outside of medial third of pinna long $(7-8 \mathrm{~mm})$; ears connected by high interauricular band with a deep midline notch (resultant skin flaps triangular, height of each flap equal

1) Instituto Nacional de Pesquisas da Amazônia (Inpa), Manaus, Brasil.

Present address: Department of Biology, York University. 4700 Keele St., Toronto ON Canada M3J 1P3. E-mail: ebernard@yorku.ca 
to width at base); cutaneous fossa present on top of head just posterior to interauricular band; second phalanx of wing digit IV shorter than first; calcar shorter than foot; mastoid breadth greater than zygomatic breadth; crown height of upper incisors not reduced; no gap between outer upper incisor and canine; P3 and P4 subequal in anteroposterior length, height of $\mathrm{P} 3$ slighly less than that of $\mathrm{P} 4 ; \mathrm{P} 4$ with small lingual heel and poorly developed lingual cusp; M1 narrower than M2; no noticeable gap between posterior edge of cingulum of M2 and anterolingual edge of M3 when toothrow seen in occlusal view; lower incisors small and bilobed; $\mathrm{p} 2$ and $\mathrm{p} 4$ subequal in anteroposterior length and height, p3 smaller in both dimensions; coronoid process high, upper margin of ascending process with steep slope (25-30 $)$.

In May $7^{\text {th }}$, 1998, during a species survey of the bat fauna of Alter do Chão ( $\left.2^{\circ} 31^{\prime} \mathrm{S}, 5^{\circ} 00^{\prime} \mathrm{W}\right)$, near Santarém, Pará State, an adult male of a small Micronycteris was collected. His characters did not resemble with the other species of Micronycteris common in that area (M. megalotis, M. minuta, and M. schmidtorum), specially a noted smooth cutaneous fossa on the top of his head between the ears, behind the interauricular band. The specimen was deposited at the Setor de Coleções Zoológicas, Instituto Nacional de Pesquisas da Amazônia, under number 2605. Posterior examinations positively identified that specimen as $M$. homezi.

Alter do Chão is in a relatively dry area dominated by Amazonian savannas (Pires \& Prance 1985; Sanaiotti \& Magnusson 1995). The savanna vegetation is dominated by grasses, with sparse clumps of shrubs, composed mainly of species from the Myrtaceae and Melastomataceae (MIRANDA 1993). Small patches of forest, ranging from 0.2 to 125 ha, also occur within the savannas. The bat fauna of Alter do Chão is being the subject of an intensive study and is composed by around 80 species, differing slightly from other sites in the Amazon Basin (BERNARD 2001; BERNARD et al. in press).

The specimen in question was captured in a mist net, set at ground level inside a small forest fragment ( $4.5 \mathrm{ha}$ ) surrounded by grass vegetation. Time of capture was 21:00 h, and the weather stable, without rain. To preserve the tissues of the cutaneous fossa, presumably a glandular pouch without similar among the other species, the skull was not removed. Comparissons between his external masures and the measures of the specimen collected in French Guiana (SIMMONS \& Voss 1998) indicated that the specimen from Alter do Chão is smaller in total length, length of the ears, hind foot, tibia, thumb, and forearm, but a little heavier (Tab. I). Presence of fur outside the pinna, and differences in the color of the dorsal and ventral fur are in accordance with the diagnosis of the species, but the specimen fom Alter do Chão present a reddish coloration, instead brownish as in the Guiana's specimen.

Alter do Chão is approximately $2000 \mathrm{~km}$ southeast from the Venezuelan area where the species was originally described, and $800 \mathrm{~km}$ south of Paracou, where the other known specimen was collected. This project a large distribution area for $M$. homezi, noted the northern-most part of South America, forming an arch from western Venezuela to French Guiana, and Central-east Amazon. Data about the biology and ecology of this species is unknown, and more captures are necessary before any expeculation. With the record of $M$. homezi, the Brazilian territory presents now 139 species of bats (MARINHO-FILHO \& SAZIMA 1998). 
Tab. I. Measurements of Micronycteris homezi captured in Alter do Chão, Santarém, Pará State, Brazil, and in Paracou, French Guiana (see text). All measures are in milimeters, and the weight in grams.

\begin{tabular}{lcc}
\hline \multicolumn{1}{c}{ Measurements } & Specimen from Alter do Chão & Specimen from Paracou \\
\hline Sex & Male & Male \\
Weight & 8.0 & 6.8 \\
Total length (a) & 55.0 & 59.0 \\
Tail length (b) & 11.0 & 11.0 \\
Hind foot length (c) & 10.8 & 11.0 \\
Tibia length (d) & 16.0 & 15.5 \\
Thumb length (e) & 6.9 & 8.1 \\
Forearm length (f) & 34.1 & 36.5 \\
Ear length $(g)$ & 19.0 & 23.0 \\
\hline
\end{tabular}

(a) Distance from the tip of the snout to the tip of the last caudal vertebra; (b) measured from the point of dorsal flexure of the tail with the sacrum to the tip of the last caudal vertebra; (c) from the anterior edge of the base of the calcar to the tip of the claw of the longest toe; (d) from the proximal end of the tibia to the posterior base of the calcar; (e) from the metacarpal-phalangial joint to the tip of the claw; (f) from the elbow to the wrist, with the wing folded; $(g)$ from the notch to the fleshy tip of the pinna.

ACKNOWLEDGEMENTS. Field work in Alter do Chão was possible thanks to a CNPq grant (521102-95.2) and an INPA-PPI grant (2-3540), both to Dr. W.E. Magnusson. Ana L.K.M. Albernaz helped with field logistics, and E. Farias helped in field collections. Species identification was possible thanks to a grant from the National Museum of Natural History, Smithsonian Institution, with special help from Dr. C.O. Handley.

\section{REFERENCES}

Bernard, E. 2001. Species list of bats (Mammalia: Chiroptera) of Santarém area, Pará State, Brazil. Revta bras. Zool. 18 (2): 455-463.

Bernard, E.; A.L.K.M. Albernaz \& W.E. Magnusson (in press). Bat species composition in three localities in the Amazon Basin. Studs Neotrop. Fauna Environ.

Marinho-Filho, J. \& I. Sazima. 1998. Brazilian bats and Conservation Biology: a first survey, p. 282-294. In: T.H. KUNZ \& P.A. RACEY (Eds.). Bat Biology and Conservation. Washington, D.C., Smithsonian Inst. Press, 365p.

MirANDA, I.S. 1993. Estrutura do estrato arbóreo do cerrado amazônico em Alter do Chão, Pará, Brasil. Revta Brasil. Bot. 16 (2): 817-823.

Pires, J.M. \& G.T. PranCE. 1985. The vegetation types of the Brazilian Amazon, p. 109-145. In: G.T. Prance \& T.E. Lovejoy (Eds). Key environments: Amazonia. Oxford, Pergamon Press, 442p.

Pirlot, P. 1967. Nouvelle récolte de chiroptères dans l'oueste du Venezuela. Mammalia 31: 260-274. SANAIOTTI, T.M \& W.E. MAGNusSON. 1995. Effects of annual fires on the production of fleshy fruits eaten by birds in a Brazilian Amazonian savanna. Jour. Trop. Ecol. 11: 53-65.

Simmons, N.B. 1996. A new species of Micronycteris (Chiroptera: Phyllostomidae) from Northeastern Brazil, with comments on phylogenetic relationships. Amer. Mus. Novitates 3158: 1-34.

Simmons, N.B. \& R.S. Voss. 1998. The mammals of Paracou, French Guiana: a Neotropical lowland rainforest fauna. Part I - Bats. Bull. Amer. Mus. Nat. Hist. 237: 1-219.

Recebido em 18.XI.1999; aceito em 22.V.2001. 